\title{
Islam v Secretary of State for the Home Department, $R v$ Immigration Appeal Tribunal and Another, ex parte Shah (1999)
}

Book or Report Section

Accepted Version

Honkala, N. (2018) Islam v Secretary of State for the Home Department, $\mathrm{R} \vee$ Immigration Appeal Tribunal and Another, ex parte Shah (1999). In: Rackley, E. and Auchmuty, R. (eds.) Women's Legal Landmarks: Celebrating the history of women and law in the UK and Ireland. Hart Publishing. ISBN 9781782259770 Available at https://centaur.reading.ac.uk/91824/

It is advisable to refer to the publisher's version if you intend to cite from the work. See Guidance on citing.

Publisher: Hart Publishing

All outputs in CentAUR are protected by Intellectual Property Rights law, including copyright law. Copyright and IPR is retained by the creators or other copyright holders. Terms and conditions for use of this material are defined in the End User Agreement. 


\section{www.reading.ac.uk/centaur}

\section{CentAUR}

Central Archive at the University of Reading

Reading's research outputs online 


\section{Islam $v$ Secretary of State for the Home Department, $R$ v Immigration Appeal Tribunal and Another, ex parte Shah (1999) \\ NORA HONKALA}

Islam $v$ Secretary of State for the Home Department, $R$ v Immigration Appeal Tribunal and Another, ex parte Shah (Conjoined Appeals)I (Islam and Shah) concerned two women - Syeda Shah and Shahanna Islam - from Pakistan who were subjected to serious physical abuse by their husbands and were forced to leave their homes. They applied for asylum in the UK claiming that they feared that if returned to Pakistan they would be subjected to domestic violence from which there was no state protection, as well as severe sanctions arising from false allegations of adultery made against them. The House of Lords decision was the first time the highest court in the UK recognised gender as a protected characteristic and women as a particular social group within the meaning of the United Nations Convention Relating to the Status of Refugees (1951) ('the Convention'). ${ }^{2}$

\section{CONTEXT}

In 2016, women represented half of the world's 19.6 million refugees. ${ }^{3}$ Women and children are often part of large-scale movements of people who flee persecution and human rights abuses, poverty and lack of economic opportunities, as well as escaping conflicts and devastation in their home countries. The significant increase in the number of armed conflicts around the world since the early 1990s has forced millions of women and girls to flee and many remain, often for years, in overcrowded refugee camps or as displaced persons within their home countries. Women and children also form the overwhelming majority of internally displaced persons (IDPs) who are especially at risk

\footnotetext{
${ }^{1}$ Islam $v$ Secretary of State for the Home Department, $R v$ Immigration Appeal Tribunal and Another, ex parte Shah [1999] UKHL 20.

21951 Convention Relating to the Status of Refugees.

${ }^{3}$ UN General Assembly, 'In Safety and Dignity: Addressing Large Movements of Refugees and Migrants, Report of the Secretary-General' (2016), UN Doc A/70/59.
} 
of violent attacks, sexual violence and abduction and who are frequently deprived of adequate shelter, food and health services.

The position of women in society, their frequent lack of means to travel and/or knowledge of their rights, as well as the particular risks they face during flight, mean that it is generally more difficult for women than men to reach a country where they can safely seek asylum. More generally women and girls continue to be subjected to serious human rights violations, including rape and other forms of sexual violence, resulting from discrimination and/or violence against them because of their gender, age and other factors.

Those women who are able to flee their home state, which is either unwilling or unable to protect them, can seek protection under the UN Refugee Convention. The Convention and its 1967 Protocol form the foundations of international refugee protection. Today, 145 states are signatories to the Convention and it is the sole legally binding international instrument that provides protection for refugees. The Convention sets out the definition of a refugee, outlines their rights, and the obligations of states to protect them. Article $1 \mathrm{~A}(2)$ defines a refugee as a person who has a well-founded fear of persecution for reasons of race, religion, nationality, membership of a particular social group (PSG) or political opinion. ${ }^{4}$ The absence of sex or gender from this list can in large part be explained by the historical context in which the Convention was drafted and adopted. The Convention was adopted in the aftermath of the Second World War. This, together with the backdrop of the Cold War, informed its understanding of who might become a refugee - namely a single, male, political activist fleeing persecution by the state. As a result, neither sex nor gender was included in the definition, indeed it was doubted whether there would ever be refugee cases on these bases. ${ }^{5}$

Subsequent feminist critique has demonstrated not only the historical contingency of this view, but its adverse impact on women claiming asylum. This critique built on the international women's rights movement - which advocated for women's rights to be taken seriously and showed the androcentric nature of

\footnotetext{
${ }^{4}$ The 1967 Protocol removed the temporal limitations of the 1951 Convention so that refugee status could be sought by all. Refugees are protected by the customary international law principle of nonrefoulement (non-expulsion or return), which prohibits the return of a refugee to a territory where she faces serious threats to her life or freedom. See also Article 33 of the Refugee Convention.

5 Thomas Spijkerboer, Gender and Refugee Status (Ashgate, 2000) 1.
} 
international law ${ }^{6}$ - and the challenge by second-wave feminists of the public/private distinction. In these ways, feminist lawyers and others have challenged the apparent downplaying of gender-related persecution within the Convention, ${ }^{7}$ and have argued for the recognition of serious harm committed against women by private individuals as a matter of public concern in international law. ${ }^{8}$

As there was no realistic option of expanding the wording of the Convention itself, strategic advances have come through ensuring gender-sensitive interpretations of the Convention. The late 1980s and early 1990s saw sustained pressure from women's rights activists, immigration advocates and scholars across a number of jurisdictions. ${ }^{9}$ The leadership and staff at the Office of the United Nations High Commissioner for Refugees (UNHCR) responded to calls for a more inclusive and proactive approach to refugee women sympathetically. ${ }^{10}$ In 1991, the UNHCR published its Guidelines on Refugee Women and the UNHCR Executive Committee issued several recommendations for states to adopt national guidelines in order for women's experiences to be recognised under the Convention, including the provision that 'women ... fearing persecution or severe discrimination on the basis of their gender should be considered a member of a social group. ${ }^{11}$ At the same time at state level, feminist collaboration and lobbying were starting to have an impact. Pressure from these groups, as well as the UNHCR, ${ }^{12}$ led to the adoption of national Gender Guidelines recognising the particular protection needs of refugee women. They also supported and advocated for women refugees in a number of high-profile immigration and asylum cases including In Re Kasinga in the United States. ${ }^{13}$ It is against this backdrop that Islam and Shah came before the House of Lords in 1999.

\footnotetext{
${ }^{6}$ Article 7 of the Covenant of the League of Nations, 1919.

${ }^{7}$ Jane Freedman, Gendering the International Asylum and Refugee Debate (Palgrave Macmillan, 2015) 75.

${ }^{8}$ Deborah Eve Anker, 'Legal Change from the Bottom Up: The Development of Gender Asylum Jurisprudence in the United States' in Efrat Arbel, Catherine Dauvergne and Jenni Millbank (eds), Gender in Refugee law: From the Margins to the Centre (Routledge, 2014$) 54$.

${ }^{9}$ Deborah Eve Anker, ibid 53.

${ }^{10}$ Arbel, Dauvergne and Millback, n 8 above, 3.

${ }^{11}$ UNHCR: Guidelines on the Protection of Refugee Women (July 1991), UN Doc ES/SCP/67.

${ }^{12}$ UNHCR Executive Committee, 'Refugee Protection and Sexual Violence', Conclusion No 73 (XLIV) (1993).

${ }^{13}$ In Re Kasinga 21 I \& N 357 (BIA 1996). See also In Re Acosta 19 I \& N Dec 211 (BIA, 1985); Canada (Attorney General) v Ward [1993] 2 SCR 689; New Zealand Refugee Status Appeals Authority (RSAA), Refugee Appeal No 1312/93 Re GJ (30 August 1995).
} 


\section{THE LANDMARK}

Syeda Shah was 43 and pregnant when she was turned out of her marital home. Shahanna Islam was a teacher in Pakistan where she lived with her husband and two children. Just prior to her leaving she had intervened in a fight at her school between two rival political factions. One of the factions subsequently made allegations of adultery against her to her husband. Both women had suffered severe violence at the hands of their husbands in Pakistan (Islam was twice admitted to hospital). They sought asylum in the UK on the basis that if they returned to Pakistan they were at risk of false allegations of adultery and would be unprotected by the state. The punishment upon a court's finding of sexual immorality includes flogging or stoning to death. The Court of Appeal had rejected the women's claim - their fear of persecution, while wellfounded, was not (as required under the Convention) for reasons of their membership of a PSG. (It was not open for the women to argue that they feared persecution as women as this was excluded from the categories in Article 1A(2)).

Prior to Shah and Islam, no case on whether women amounted to a PSG had reached the House of Lords. The Home Office had consistently attempted to stymie such cases by offering to some women exceptional leave to remain - as it had done in this case. However, both Islam and Shah wanted to obtain refugee status, which provides a stronger form of protection as a result of international law obligations toward refugees placed on receiving states. Emboldened by progress overseas, feminist and refugee advocates in the UK had been working hard to get a test case heard. The Refugee Women's Legal Group (RWLG), set up by feminist scholars, refugee women, lawyers and activists in 1996, was instrumental in raising awareness on the particular difficulties women asylum-seekers faced when their claims were decided. Its founding members were Hildegard Dumper (Refugee Action), Minoo Jalali (Avon and Bristol Law Centre), Monireh Moftizadeh (Asylum Aid), Heaven Crawley (academic), Jane Coker and Alison Stanley (ILPA) and Victoria Tennant (Refugee Legal Centre), and others soon joined. The group's aim was to bring a gendered perspective to refugee law and policy. In June 1997, written by Heaven Crawley and together with ILPA and Refugee Action, the RWLG produced Women as Asylum Seekers: A Legal Handbook. The Handbook sought to provide information for legal practitioners and others working with asylum-seeker women about the ways in which the asylum procedure could be 
made more accessible and sensitive to asylum-seeker women's experiences. ${ }^{14}$

Following the publication of the Handbook and responding to international developments of provision of national gender guidelines in other countries, RWLG established a drafting committee in order to produce Gender Guidelines for determination of women's claims for refuge in the UK. The drafting committee drew from a wide range of experiences including members of the legal profession, academics and representatives from NGOs and other organisations (Amnesty International, Asylum Aid, ILPA, the Joint Council for the Welfare of Immigrants (JCWI), the Immigration Advisory Service (IAS), Refugee Action, the Refugee Council, the Refugee Legal Centre (RLC), Southall Black Sisters and the UNHCR). The draft document was then circulated for consultation and discussion to refugee community organisations, women's groups, human rights groups and NGOs working with refugees and asylum-seekers in the UK, as well as crucially to asylum-seeking women themselves. The Gender Guidelines for the Determination of Asylum Claims in the UK were published in July $1998 .{ }^{15}$ These defined gender-specific persecution as comprising serious harm and a failure of state protection. In Shah and Islam, Lord Hoffmann referred to the Guidelines and accepted their formulation

What is the reason for the persecution which the appellants fear? Here it is important to notice that it is made up of two elements. First, there is the threat of violence to Mrs Islam by her husband and his political friends and to Mrs Shah by her husband. This is a personal affair, directed against them as individuals. Secondly, there is the inability or unwillingness of the State to do anything to protect them. There is nothing personal about this. The evidence was that the State would not assist them because they were women. It denied them a protection against violence which it would have given to men. These two elements have to be combined to constitute persecution within the meaning of the Convention. As the Gender Guidelines for the Determination of Asylum Claims in the UK (published by the Refugee Women's Legal Group in July 1988 [sic]) succinctly puts it (at p 5): 'Persecution = Serious Harm + The Failure of State Protection'.

The Lords, by a majority, held that the women had a well-founded fear of persecution because they would not be protected by their state, which partly tolerated and partly sanctioned their discrimination. Vitally, the Lords also accepted that their fear of persecution was for reasons of their membership of a PSG. The Lords held that while members of a PSG shared a common, immutable characteristic that was either

\footnotetext{
${ }^{15}$ Refugee Women's Legal Group, Gender Guidelines for the Determination of Asylum Claims in the UK (RWLG, 1998). See further discussion in Sue Kirvan, 'Women and Asylum: A particular Social Group' (1999) 7(3) Feminist Legal Studies 333, 337-40.
} 
beyond the power of an individual to change or was so fundamental to the individual's identity that it ought not to be required to be changed, it was not required under Article 1A(2) of the Convention that a PSG should be cohesive, although cohesiveness could prove the existence of a particular social group. On this basis, gender was considered to be an immutable characteristic allowing the women to be members of a necessary PSG, defined variously as 'women of Pakistan' and 'Pakistani women ... accused of transgressing social mores (in the instant case, adultery, disobedience to husbands) ... who were unprotected by their husbands or other male relatives'.

\section{WHAT HAPPENED NEXT}

Since Shah and Islam, courts have accepted arguments that persecutory actions toward a PSG may be a relevant factor in determining the visibility of that group in a particular society. Women fleeing domestic violence from China, Ethiopia, Iran, Kenya, Moldova, Sierra Leone, Somalia, Albania, Afghanistan and Ukraine have been recognised as refugees on the basis of entrenched discrimination and lack of state protection. ${ }^{16}$ Shah and Islam has been followed and further developed in other jurisdictions, including New Zealand ${ }^{17}$ and Australia, where Gleeson CJ commented:

It is power, not number, that creates the conditions in which persecution may occur. ... Women in any society are a distinct and recognisable group, and their distinctive attributes and characteristics exist independently of the manner in which they are treated, either by males or by governments. ${ }^{18}$

In 2002, the UNHCR published its guidelines specifically addressing genderrelated persecution in which it stated that: 'Gender-related claims have typically encompassed, although are by no means limited to, acts of sexual violence, family/domestic violence, coerced family planning, female genital mutilation, punishment for transgression of social mores, and discrimination against homosexuals. ${ }^{19}$

\footnotetext{
${ }^{16}$ Frances Webber, “'As a woman I have no country”: The Denial of Asylum to Women Fleeing Genderbased Persecution' (Women for Refugee Women, 2012) 5.

${ }^{17}$ New Zealand Refugee Status Appeals Authority (RSAA), Refugee Appeal No 71427/99 (16 August 2000).

${ }^{18}$ Minister for Immigration \& Multicultural Affairs v Khawar [2002] HCA 14 [33], [35].

${ }^{19}$ UNHCR, Guidelines on International Protection: Gender-Related Persecution within the Context of Article 1A(2) of the 1951 Convention and/or its 1967 Protocol relating to the Status of Refugees (Geneva, May 2002), UN Doc HCR/GIP/02/01 [3].
} 
In the UK, the Asylum Directorate's instructions to decision-makers on the definition of particular social groups within the meaning of the Convention have been revised. ${ }^{20}$ Gender Guidelines specifically aimed at the judiciary, which drew from the RWLG Guidelines, were adopted in $2000 .{ }^{21}$ The RWLG continued to lobby members of Parliament to ensure the official adoption of their guidelines by the Home Office. ${ }^{22}$ With the help of RWLG, Asylum Aid set up its Refugee Women's Resources Project to deal with questions of gender and asylum and to work with RWLG in lobbying the government. Finally, the Home Office agreed to work together with RWLG and with the UNHCR's representative in the UK to draw up its own guidelines, which were adopted in 2004.

Shah and Islam was not the last time the House of Lords considered the scope of a PSG. In Secretary of State for the Home Department $v$ K; Fornah v Secretary of State for the Home Department ${ }^{23}$ they considered whether it extended to women fleeing the threat of Female Genital Mutilation (FGM). Overturning the Court of Appeal, and following Shah and Islam, the Lords held that it did. It is perhaps unsurprising that the most strongly-worded response came from Lady Hale - the first woman and openly feminist - member of the Appellate Committee. For her the answer as to whether FGM amounted to gender-related and gender-specific persecution was

so blindingly obvious that it must be a mystery to some why [the cases] had to reach this house ... the world has woken up to the fact that women as a sex may be persecuted in ways which are different from the ways in which men are persecuted and that they may be persecuted because of their inferior status accorded to their gender in their home society. ${ }^{24}$

\section{SIGNIFICANCE}

The decision in Shah and Islam was groundbreaking in its acceptance of gender as a protected characteristic under the Convention. In so doing, the House of Lords demonstrated not only a willingness to take women's rights seriously but, more broadly, the non-discriminatory objective and purpose of the Refugee Convention. The case

\footnotetext{
${ }^{20}$ Heaven Crawley, Refugees and Gender: Law and Process (Jordans, 2001) 77.

${ }^{21}$ Immigration Appellate Authority (UK): Asylum Gender Guidelines, 1 November 2000.

${ }^{22}$ Freedman, n 7 above, 102.

${ }^{23}$ Secretary of State for the Home Department v K; Fornah v Secretary of State for the Home Department [2006] UKHL 46.

24 ibid, [83], [86].
} 
consolidated emerging consensus on the need for a gender-sensitive interpretation of PSG and took a holistic approach in its recognition of the women, who were persecuted because they were women, as refugees.

Of course, challenges remain for refugee women and the advocates supporting them. There is still much work to do to achieve gender-sensitive interpretation of the Convention. Research suggests that first-instance decision-makers in the UK systematically fail to consider PSG in relation to gender-persecution claims and that the Gender Guidelines are regularly not adhered to. ${ }^{25}$ Moreover, a political climate which has seen increasing support for restrictive immigration and asylum policies has contributed to fears of less generous interpretations of PSG in the future, where the category of 'women' is at risk of being seen as too wide and an implicit 'floodgates' risk.

In the meantime, however, Sue Kirvan suggests, 'for feminists the cases of Islam and Shah address debates as to the most empowering arguments and useful strategies to employ in order to further the protection of refugee women' ${ }^{26}$ Without doubt, the claimants in Islam and Shah were beneficiaries of the feminist strategies of the 1970s, the legacy of Women's Aid and others in moving understandings of, and responses to, 'domestic' violence out of the 'private' and into the 'public' sphere. However, it is important that the debate continues to move on. More recently, the focus of feminists working in this area has shifted to challenging the tendency to deploy the PSG in all women refugees' claims. In fact, many asylum cases involving women might also (or instead) involve a well-founded fear of persecution for reasons of a 'political opinion'. The women have been involved in active resistance, transgression of social norms and/or institutional discrimination. The inherently political nature of these - and other - asylum claims means that feminist activism in this area is as important as ever.

\section{Further reading}

- Efrat Arbel, Caterine Dauvergne and Jenni Millbank (eds), Gender in

\footnotetext{
${ }^{25}$ See, Helen Muggeridge and Chen Maman, 'Unsustainable: The Quality of Initial Decision-making in Women's Asylum Claims' (Asylum Aid, 2011) and Sophia Ceneda and Clare Palmer, "Lip Service” or Implementation?; The Home Office Gender Guidance and Women's Asylum Claims in the UK' (Asylum Aid, Women's Refugee Project, 2006).

${ }^{26}$ Kirvan, n 15 above, 340.
} 
Refugee Law: From the Margins to the Centre (Routledge, 2014).

- Heaven Crawley, Refugees and Gender: Law and Process (Jordans, 2001).

- Alice Edwards, 'Transitioning Gender: Feminist Engagement with International Refugee Law and Policy 1950-2010' (2010) 29(2) Refugee Survey Quarterly 21. 